\title{
Perbedaan status gizi, kesegaran jasmani, dan kualitas hidup anak sekolah di pedesaan dan perkotaan
}

\author{
The comparison of nutritional status, physical fitness and quality of life of urban and rural school children
}

Maria Mexitalia ${ }^{1}$, Hendriani Selina ${ }^{1}$, Mohammad Syarofil Anam $^{1}$, Aya Yoshimura $^{2}$, Taro Yamauchi ${ }^{2}$, Nurkukuh $^{3}$, Bambang Hariyana $^{3}$

\begin{abstract}
Background: The differences in geographic, sosioeconomic and lifestyle between children in rural and urban areas influence their nutritional status. The urban children tended to be less active. The evidence suggested that physical activity improves cardiorespiratory fitness and mental health in young people but study that compare those indicators among rural and urban children was scarce.

Objective: To compare the nutritional status, physical fitness, and quality of life between elementary school children in rural and urban areas.

Methods: A cross-sectional study was conducted at Semarang (urban) and Mlonggo (rural) Central Java in 2009. Inclusion criteria was school children aged 9-11 years and had no physical disability. Body composition was measured by Bioelectrical Impedance Analysis, physical activity by Global Physical Activity Questionnaire (GPAQ), physical fitness by 20-m shuttle run test and quality of life by Pediatrics Quality of Life Questionnaire (PedQoL 4.0). The differences between nutritional status and physical activity were assessed by Chi Square test, while the differences between physical fitness and quality of life were tested by independent $t$ test $(p<0.05)$.

Results: One hundred sixty-two subjects were enrolled in the study (Semarang 82 students; 36 boys, 46 girls and Mlonggo 80 students; 40 boys, 40 girls). Body mass index (18.97 vs $\left.15.16 \mathrm{~kg} / \mathrm{m}^{2}\right)$ and body fat $(26.03 \% \mathrm{vs} 18.03 \%)$ of urban children were higher than that of the rural's $(p<0.001)$. Children in rural area were significantly more active, have higher physical fitness level (VO2 max 28.54 $\pm 1.79 \mathrm{ml} / \mathrm{kg} / \mathrm{min}$ vs $21.57 \pm 1.79 \mathrm{ml} / \mathrm{kg} / \mathrm{min})(p<0.01)$, and have higher score in quality of life $(2243 \pm 295,8)$ compared to the children from urban area $(2133 \pm 369.4)(p<0.05)$.

Conclusion: Rural school children have lower nutritional status than urban children, but they are more active and have higher physical fitness level. They also have better quality of life.
\end{abstract}

KEY WORDS nutritional status, physical activity, physical fitness, quality of life, school age children

\begin{abstract}
ABSTRAK
Latar belakang: Perbedaan geografis dan sosioekonomi daerah pedesaan dan perkotaan dapat mempengaruhi status gizi anak. Anak di perkotaan cenderung tidak aktif dan mempunyai berat badan lebih dibandingkan di pedesaan. Didapatkan bukti bahwa aktivitas fisik akan meningkatkan kesegaran jasmani dan mental tetapi penelitian yang membandingkan kondisi keduanya di desa dan kota masih jarang.

Tujuan: Membuktikan perbedaan status gizi, aktivitas fisik, kesegaran jasmani, dan kualitas hidup anak di daerah pedesaan dan perkotaan.

Metode: Penelitian potong lintang dilakukan pada anak SD di daerah perkotaan dan pedesaan pada bulan Agustus 2009. Kriteria inklusi adalah anak SD usia 9-11 tahun dan tidak mempunyai kecacatan fisik. Komposisi tubuh diukur dengan Bioelectrical Impedance Analysis, aktivitas fisik menggunakan Global Physical Activity Questionnairre (GPAQ), kesegaran jasmani dengan $20 \mathrm{~m}$ shuttle run test, dan kualitas hidup menggunakan kuesioner Pediatrics Quality of Life (PedsQOL) meliputi penilaian fungsi fisik, mental, sosial, sekolah, dan diri sendiri. Uji statistik dengan Chi Square untuk status gizi dan aktivitas fisik, independent $t$-test untuk kesegaran jasmani dan kualitas hidup $(p<0,05)$.

Hasil: Penelitian diikuti 162 subjek, 82 subjek (36 laki-laki dan 46 perempuan) dari perkotaan (Semarang) dan 80 subjek (40 laki-laki dan 40 perempuan) dari pedesaan (Mlonggo). Indeks massa tubuh anak perkotaan $\left(18,97 \mathrm{~kg} / \mathrm{m}^{2}\right)$ lebih tinggi dibandingkan daerah pedesaan $\left(15,16 \mathrm{~kg} / \mathrm{m}^{2}\right)(p<0,001)$. Anak di pedesaan lebih aktif secara bermakna $(p<0,001)$, mempunyai kesegaran jasmani yang diukur dengan VO2 max lebih tinggi (pedesaan 28,54 $\pm 1,79 \mathrm{ml} / \mathrm{kg} /$ menit) dibandingkan anak di perkotaan $(21,57 \pm 1,79 \mathrm{ml} / \mathrm{kg} / \mathrm{menit})(p<0,001)$, serta kualitas hidup yang lebih tinggi berdasarkan skor total kualitas hidup (pedesaan $2243 \pm 295,8$ dibanding perkotaan $2133 \pm 369,4 ; p<0,05$ ).

Kesimpulan: Anak sekolah di pedesaan memiliki status gizi yang lebih rendah dibandingkan di perkotaan, tetapi mereka lebih aktif, memiliki tingkat kesegaran jasmani dan kualitas hidup yang lebih tinggi.
\end{abstract}

KATA KUNCI: status gizi, aktivitas fisik, kesegaran jasmani, kualitas hidup, anak sekolah

\footnotetext{
1 Departemen Ilmu Kesehatan Anak Fakultas Kedokteran Universitas Diponegoro / Rumah Sakit Umum Pusat Dr. Kariadi Semarang, Jl. Dr. Soetomo No 18, Semarang, e-mail: maria_mexitalia@yahoo.com

${ }^{2}$ Department of Human Ecology Faculty of Health Sciences, Hokkaido University, Japan, Kitaku Sapporosi Hokkaido Japan, e-mail: taroy@med. hokudai.ac.jp

${ }^{3}$ Laboratorium IImu Kesehatan Masyarakat Fakultas Kedokteran Universitas Diponegoro, Kecamatan Mlonggo Kabupaten Jepara, e-mail: bhariyana@ yahoo.co.id
} 


\section{PENDAHULUAN}

Lingkungan merupakan salah satu faktor yang mempengaruhi kesehatan anak. Perbedaan geografi, sosioekonomi, dan gaya hidup antara penduduk di pedesaan dan perkotaan dapat mempengaruhi tingkat kesehatan anak (1). Dikotomi pedesaan dan perkotaan dihubungkan dengan tingkat pendidikan, pendapatan, dan kesehatan, yaitu penduduk yang tinggal di daerah pedesaan memiliki parameter sosioekonomi dan kesehatan yang lebih rendah dibandingkan di perkotaan (2). Di Amerika Serikat pada tahun 2005, dilaporkan bahwa tingkat kemiskinan dan status kesehatan penduduk di pedesaan lebih rendah dibandingkan dengan penduduk di perkotaan (3).

Penelitian-penelitian yang dilakukan di berbagai negara menunjukkan perbedaan status gizi anak di daerah perkotaan dan pedesaan. Penelitian di Afrika pada tahun 2005 mendapatkan hasil bahwa anak-anak di daerah perkotaan memiliki status gizi yang lebih tinggi berdasarkan indeks massa tubuh (IMT) dibandingkan dengan anak di daerah pedesaan (4). Penelitian serupa di Pakistan tahun 2003 pada 2042 subjek, mendapatkan hasil bahwa di daerah pedesaan $45,3 \%$ anak memiliki status gizi kurang dibandingkan $32,3 \%$ di daerah perkotaan (5). Lingkungan yang tidak sehat dan pelayanan kesehatan yang rendah diduga menyebabkan perbedaan status gizi anak di daerah pedesaan dan perkotaan (1-3).

Aktivitas fisik dan kesegaran jasmani merupakan dua hal yang dapat mempengaruhi status kesehatan anak. Penelitian di Belanda pada tahun 2007 melaporkan adanya hubungan yang bermakna antara aktivitas fisik dan lingkungan pada anak (6). Lingkungan dengan tingkat sosioekonomi yang rendah dapat mempengaruhi akses terhadap makanan, pelayanan kesehatan, dan kesempatan untuk melakukan aktivitas fisik yang adekuat. Di samping itu, pola hidup yang tidak aktif, rendahnya aktivitas fisik, dan tingkat kesegaran jasmani pada anak di daerah perkotaan menyebabkan meningkatnya frekuensi obesitas, diabetes mellitus, dan risiko penyakit kardiovaskuler pada anak. Sebaliknya anak di daerah pedesaan cenderung memiliki persepsi diri yang rendah (7).

Penelitian di Bangladesh pada tahun 2006 menunjukkan bahwa dengan menggunakan kuesioner World Health Organization (WHO) didapatkan perbedaan kualitas hidup antara anak di daerah pedesaan dan perkotaan (8). Berbeda dengan penelitian tersebut, suatu penelitian di Amerika Serikat pada 1469 subjek anak sekolah, tidak didapatkan perbedaan yang bermakna antara anak di daerah pedesaan dan perkotaan dalam hal persepsi diri, kompetensi skolastik, dan kualitas hidup (9). Oleh karena itu penelitian ini dilakukan dengan tujuan untuk melihat perbedaan status gizi, aktivitas fisik, kesegaran jasmani, dan kualitas hidup antara anak yang tinggal di daerah pedesaan dan perkotaan.

\section{BAHAN DAN METODE}

Penelitian potong lintang dilakukan pada bulan Agustus 2009 di SD Bernardus Semarang sebagai kategori daerah perkotaan dan SD Mlonggo I sebagai kategori daerah pedesaan. Sampel penelitian diambil secara consecutive dengan metode berjenjang, untuk daerah pedesaan dan perkotaan ditentukan dua daerah yaitu Kodya Semarang dan Kabupaten Jepara. Sedangkan SD tempat penelitian berlangsung ditentukan dengan pertimbangan kemudahan akses tanpa mengurangi definisi perkotaan dan pedesaan yang telah ditentukan sebelumnya. Besar sampel dihitung berdasarkan perkiraan beda rerata dua populasi dengan tingkat kepercayaaan $95 \%$, besaran proporsi $1\left(P_{1}\right) 10 \%$, dan besaran proporsi $2\left(\mathrm{P}_{2}\right) 30 \%$, maka dibutuhkan sampel minimal sebesar 47 subjek pada masing-masing kelompok (8). Kriteria inklusinya yaitu anak sekolah berusia 9-11 tahun, sehat, tidak menderita penyakit kronik, kelainan tulang dan otot, serta asma yang diinduksi oleh latihan. Kriteria eksklusinya adalah subjek yang menolak berpartisipasi.

Pengukuran antropometri dilakukan untuk menilai berat badan dan lemak tubuh diukur dengan timbangan Tanita $B C$ 545 Inner Scan Body Composition yang telah distandarisasi. Penimbangan dilakukan dengan melepas sepatu namun masih menggunakan seragam olahraga sekolah. Tinggi badan diukur menggunakan wall-mounted stadiometer dengan tingkat ketelitian $0,1 \mathrm{~cm}$. Pengukuran dilakukan dalam posisi tegak, tanpa memakai alas kaki, dan muka menghadap lurus ke depan. Kemudian ditentukan nilai IMT dengan rumus berat badan (kg) dibagi kuadrat tinggi badan (meter). Kriteria status gizi ditentukan berdasarkan International Obesity Task Force dengan kurva Centers for Disease Control (CDC) 2000 yaitu seorang anak dikategorikan mengalami obesitas bila IMT lebih dari atau sama dengan persentil ke-95, berat badan lebih (overweight) bila IMT lebih dari atau sama dengan persentil ke-85 dan kurang dari persentil ke-95, status gizi normal apabila IMT lebih dari atau sama dengan persentil ke-5 dan kurang dari persentil ke-85, dan status gizi kurang apabila kurang dari persentil ke-5 $(9,10)$.

Aktivitas fisik dinilai menggunakan Global Physical Activity Questionairre (GPAQ) dan dikategorikan berdasarkan nilai metabolic equivalent (METs) yang merupakan rasio laju metabolik saat kerja terhadap laju metabolik saat istirahat. Kategori aktivitas fisik dibagi menjadi aktif dan tidak aktif/pasif. Berdasarkan METs ada beberapa klasifikasi aktifitas fisik yaitu: 1) Vigorous jika seseorang yang melakukan aktivitas vigorous (dengan METs $\geq 6$ dan membutuhkan penggunaan otot-otot besar secara ritmis) minimal 3 kali per minggu dengan waktu minimal 20 menit per sesi; 2) Adekuat jika seseorang yang melakukan aktivitas minimal 3 jam dan terbagi dalam minimal 5 sesi seminggu dengan intensitas aktivitas sedang ( $\geq 3,5$ METs); 3) Inadekuat jika tidak termasuk dalam 2 kategori di atas. Kategori vigorous dan adekuat 
dikelompokkan sebagai aktif dan kategori inadekuat dikelompokkan sebagai pasif (11).

Tingkat kesegaran jasmani diukur menggunakan tes 20 m multistage shuttle run test. Pengukuran dilakukan dengan cara anak dites berlari secara ulang alik sejauh 20 meter, sambil mendengar serangkaian bunyi sinyal yang direkam dalam compact disc. Kemudian hasil tes akan dikonversikan dalam VO2 max dengan menggunakan kalkulator VO2 max yang tersedia secara online (www. aminoz.com). Langkahnya dengan memasukkan level pencapaian peserta dan berat badannya kemudian akan keluar nilai VO2 max-nya. Selanjutnya nilai tersebut dimasukkan ke dalam kurva tingkat kesegaran jasmani dan dikategorikan menjadi kurang sekali, kurang, cukup, rata-rata, baik, dan baik sekali (12).

Kualitas hidup dinilai dengan menggunakan kuesioner Pediatrics Quality of Life (PedsQOL) 4.0 yang telah distandarisasi secara internasional, terdiri dari penilaian fungsi fisik, mental, sekolah, dan sosial. Masingmasing fungsi memuat pertanyaan-pertanyaan yang harus dijawab oleh peserta dengan kategori sering sekali, sering, kadang-kadang, dan tidak pernah. Masing-masing jawaban memiliki skor dengan nilai semakin sering maka semakin rendah nilai skornya. Analisis data menggunakan program komputerisasi dengan uji Chi Square dan independent $t$-test.

Penelitian ini sudah memperoleh ethical clearance dari Komite Etik Fakultas Kedokteran Universitas Diponegoro/Rumah Sakit Dr. Kariadi Semarang. Setiap anak yang dilakukan pemeriksaan dan menjadi subjek dalam penelitian ini telah memperoleh persetujuan dari orangtua/wali dengan mengisi formulir informed consent secara tertulis.

\section{HASIL}

Rerata umur subjek penelitian di daerah pedesaan 10,18 tahun, sedangkan di perkotaan rerata umur subjek 9,9 tahun. Tidak didapatkan perbedaan bermakna pada karakteristik subjek penelitian (Tabel 1).

Tabel 1. Karakteristik umum subjek penelitian

\begin{tabular}{cccc}
\hline Karakteristik & $\begin{array}{c}\text { Pedesaan } \\
(\mathbf{n = 8 0 )}\end{array}$ & $\begin{array}{c}\text { Perkotaan } \\
(\mathbf{n = 8 2})\end{array}$ & $\mathbf{p}$ \\
\hline Jenis kelamin & & & \\
Laki-laki & 40 & 36 & $0,437^{\mathrm{a}}$ \\
Perempuan & 40 & 46 & \\
Umur (tahun) & $10,18 \pm 0,3$ & $9,9 \pm 1,1$ & $0,359^{\mathrm{b}}$ \\
\hline
\end{tabular}

Keterangan: ${ }^{\mathrm{a} C h i}$ Square ${ }^{\mathrm{b}}$ Independent $t$ test

\section{Status gizi}

Didapatkan perbedaan yang bermakna terhadap berat badan, lemak tubuh, dan tinggi badan antara anak di daerah pedesaan dan perkotaan. Berat badan, tinggi
Tabel 2. Antropometri, tingkat aktivitas fisik, kesegaran jasmani, dan skor kualitas hidup subjek

\begin{tabular}{|c|c|c|c|}
\hline Variabel & $\begin{array}{c}\text { Pedesaan } \\
(n=80)\end{array}$ & $\begin{array}{c}\text { Perkotaan } \\
(n=82)\end{array}$ & p \\
\hline Berat badar & $26,75 \pm 4,8$ & $36,15 \pm 10,0$ & $0,001^{a *}$ \\
\hline Tinggi badan $(\mathrm{cm})$ & $132,4 \pm 6,8$ & $137,4 \pm 5,6$ & $0,001^{a *}$ \\
\hline Lemak tubuh (\%) & $18,02 \pm 4,35$ & $26,03 \pm 6,25$ & $0,001^{a *}$ \\
\hline IMT (kg/m²) & 15,1 & 4,34 & $0,001^{a *}$ \\
\hline \multicolumn{4}{|l|}{ Aktivitas fisik } \\
\hline $\begin{array}{l}\text { Aktif } \\
\text { Tidak aktif }\end{array}$ & $\begin{array}{c}75(93,75 \%) \\
5(6,25 \%)\end{array}$ & $\begin{array}{l}61(74,39 \%) \\
21(25,61 \%)\end{array}$ & $0,001^{\mathrm{b*}}$ \\
\hline \multicolumn{4}{|l|}{ Kesegaran jasmani } \\
\hline $\begin{array}{l}\text { VO2max } \\
\text { (ml/kg/menit) }\end{array}$ & $28,54=$ & 1,79 & $<0,001$ \\
\hline \multicolumn{4}{|l|}{ Kualitas hidup } \\
\hline $\begin{array}{l}\text { Fungsi fisik } \\
\text { Fungsi mental } \\
\text { Fungsi sosial } \\
\text { Fungsi sekolah } \\
\text { Fungsi diri } \\
\text { Total }\end{array}$ & $\begin{array}{c}658,8 \pm 87,5 \\
350,3 \pm 74,1 \\
382,2 \pm 74,6 \\
355,6 \pm 67,0 \\
497,2 \pm 76,9 \\
2243,1 \pm 295,8\end{array}$ & $\begin{array}{c}599,7 \pm 109,2 \\
311,6 \pm 98,4 \\
371,6 \pm 89,2 \\
357,6 \pm 78,9 \\
491,8 \pm 88,9 \\
2133,8 \pm 369,4\end{array}$ & $\begin{array}{c}<0,001^{a *} \\
0,013^{a^{*}} \\
0,576^{a} \\
0,930^{a} \\
0,988^{a} \\
0,045^{a^{\star}}\end{array}$ \\
\hline
\end{tabular}

Keterangan: a Mann-whitney ${ }^{\mathrm{b}}$ Chi Square

IMT = indeks massa tubuh

* = signifikan $\mathrm{p}<0,05$

badan, dan lemak tubuh subjek daerah perkotaan lebih tinggi dibandingkan dengan subjek daerah pedesaan.

Dengan menggunakan IMT, diperoleh $25 \%$ subjek daerah pedesaan memiliki status gizi kurang dibandingkan dengan $6,09 \%$ di daerah perkotaan dan $72,5 \%$ memiliki status gizi normal di daerah pedesaan sedangkan daerah perkotaan sebesar $56,09 \%$. Tidak ada subjek yang memiliki status gizi obesitas di daerah pedesaan dibandingkan dengan daerah perkotaan yang ditemukan $19,52 \%$ subjek memiliki status gizi obesitas. Berdasarkan rerata IMT, didapatkan perbedaan yang bermakna antara pedesaan dan perkotaan. IMT subjek daerah perkotaan lebih tinggi dibandingkan dengan daerah pedesaan dengan rerata 18,96 $\pm 4,34 \mathrm{~kg} / \mathrm{m}^{2}$ dibanding $15,16 \pm 1,69 \mathrm{~kg} / \mathrm{m}^{2}(p<0,001)$ (Tabel 2).

\section{Aktivitas fisik dan kesegaran jasmani}

Tujuh puluh lima subjek $(93,75 \%)$ dari daerah pedesaan memiliki tingkat aktivitas fisik dengan kategori aktif, sedangkan 5 subjek $(6,25 \%)$ termasuk kategori tidak aktif. Sedangkan di daerah perkotaan 61 subjek $(74,39 \%)$ memiliki kategori aktif dan 21 subjek $(25,61 \%)$ termasuk kategori tidak aktif. Anak di daerah pedesaan memiliki tingkat aktivitas fisik yang lebih aktif dibandingkan dengan anak di daerah perkotaan $(p<0,001)$ (Tabel 2).

Tingkat kesegaran jasmani dinyatakan dengan nilai VO2 $\max (\mathrm{ml} / \mathrm{kg} / \mathrm{menit}$ ), didapatkan hasil perbedaan yang bermakna rerata $\mathrm{VO} 2$ max pada kedua kelompok. Subjek di daerah pedesaan memiliki rerata $V O 2$ max $28,54 \pm 1,79 \mathrm{ml} / \mathrm{kg} /$ menit dibandingkan dengan subjek daerah perkotaan sebesar $21,57 \pm 1,79 \mathrm{ml} / \mathrm{kg} / \mathrm{menit}$ (Tabel 2). Sedangkan berdasarkan 
kategori tingkat kesegaran jasmani, subjek daerah perkotaan seluruhnya termasuk dalam kategori kurang sekali dengan nilai batas VO2 $\max 34 \mathrm{ml} / \mathrm{kg} / \mathrm{menit}$, sedangkan di daerah pedesaan 69 subjek $(86,25 \%)$ termasuk kategori kurang sekali, 10 subjek (12,5\%) kategori kurang, dan hanya satu subjek $(1,25 \%)$ dengan kategori cukup.

\section{Kualitas hidup}

Berdasarkan kuesioner PedsQOL didapatkan perbedaan skor total antara subjek penelitian di daerah pedesaan dan perkotaan dengan nilai skor masing-masing $2243,1 \pm 295,8$ dan 2133,8 $\pm 369,4$ ( $p=0,045)$ (Tabel 2). Sedangkan berdasarkan penilaian masing-masing fungsi, didapatkan perbedaan hanya pada fungsi fisik dan mental sedangkan fungsi sosial, sekolah, dan fungsi diri tidak didapatkan perbedaan yang bermakna. Subjek di daerah pedesaan memiliki skor untuk fungsi fisik dan mental yang lebih tinggi dibandingkan dengan subjek daerah perkotaan $(p=0,013)$.

\section{BAHASAN}

Berdasarkan IMT, didapatkan subjek dari daerah pedesaan dengan gizi kurang yang lebih tinggi dibandingkan dengan perkotaan, sedangkan gizi lebih dan obesitas lebih banyak terjadi pada subjek daerah perkotaan. Kondisi sosial ekonomi dan ketersediaan ragam makanan merupakan faktor yang mempengaruhi kondisi tersebut. Hasil yang menarik pada penelitian ini yaitu ditemukan prevalensi gizi lebih pada $2,5 \%$ subjek daerah pedesaan. Bila dibandingkan dengan beberapa penelitian sebelumnya masih didapatkan perbedaan, penelitian di Pakistan ternyata tidak menemukan perbedaan status gizi pada anak daerah pedesaan dan perkotaan (5), sedangkan di Amerika Serikat didapatkan perbedaan yang bermakna (3). Penelitian di New Zealand mendapatkan hasil yang sama dengan penelitian ini yaitu subjek di daerah pedesaan memiliki IMT yang lebih rendah dibandingkan dengan subjek di perkotaan (13). Perbedaan hasil penelitian dengan beberapa penelitian sebelumnya mungkin karena pada subjek penelitian ini, daerah perkotaan tingkat sosial ekonominya tergolong tinggi sehingga status gizinya pun tinggi, sedangkan subjek dari daerah pedesaan rata-rata memiliki tingkat sosial ekonomi yang rendah.

Aktivitas fisik subjek daerah pedesaan lebih tinggi secara bermakna dibandingkan dengan subjek daerah perkotaan, hal ini disebabkan subjek di daerah pedesaan sebagian besar menggunakan sepeda atau berjalan kaki saat berangkat sekolah, sedangkan subjek di daerah perkotaan sebagian besar diantar menggunakan kendaraan roda empat maupun roda dua oleh orangtuanya. Sementara itu program olahraga di sekolah sebagai salah satu sarana untuk beraktivitas frekuensinya sama. Sebuah penelitian di
Yunani (14) mendapatkan hasil pada musim dingin subjek daerah perkotaan lebih aktif dibandingkan dengan pedesaan, sedangkan pada musim panas subjek daerah pedesaan lebih aktif. Penelitian tersebut menggunakan pedometer untuk menentukan tingkat aktivitas fisik sedangkan penelitian ini menggunakan kuesioner GPAQ. Berbeda dengan penelitian di Amerika Serikat pada tahun 2008 yang mendapatkan hasil bahwa subjek di daerah perkotaan memiliki tingkat aktivitas fisik yang lebih tinggi dibandingkan dengan subjek di pedesaan, mereka menggunakan kuesioner untuk menentukan tingkat aktivitas fisik (15). Perbedaan hasil tersebut mungkin dipengaruhi oleh faktor sosiobudaya setempat, di samping itu kondisi cuaca juga dapat mempengaruhi perbedaan hasil dengan penelitian ini. Meskipun begitu, didapatkan kesesuaian hubungan antara aktivitas fisik dan IMT, subjek yang memiliki aktivitas fisik tinggi menunjukkan IMT yang lebih rendah dibandingkan dengan mereka yang tidak aktif.

Tingkat kesegaran jasmani subjek daerah pedesaan lebih tinggi dibandingkan dengan subjek daerah perkotaan, dengan rerata nilai VO2 $\max 28,54 \pm 1,79 \mathrm{ml} / \mathrm{kg} / \mathrm{menit}$ dibandingkan dengan 21,57 $\pm 1,79 \mathrm{ml} / \mathrm{kg} /$ menit. Meskipun demikian anak sekolah di daerah pedesaan dan perkotaan keduanya memiliki tingkat kesegaran jasmani yang rendah dengan nilai batas VO2 max $30 \mathrm{ml} / \mathrm{kg} /$ menit berdasarkan jenis kelamin dan berat badan.

Sebuah penelitian di India pada tahun 2010 mendapatkan hasil bahwa anak di daerah pedesaan memiliki tingkat kesegaran jasmani yang lebih tinggi dibandingkan dengan perkotaan (16). Penelitian berbeda di Eropa pada tahun 2005 tidak mendapatkan perbedaan yang bermakna pada tingkat kesegaran jasmani antara anak di daerah pedesaan dan perkotaan (17). Begitu juga dengan penelitian lain di India yang tidak mendapatkan perbedaan bermakna antara subjek daerah pedesaan dan perkotaan terhadap nilai VO2 max. Perbedaan hasil tersebut kemungkinan karena metode yang digunakan untuk menentukan tingkat kesegaran jasmani berbedabeda.

Penelitian ini menggunakan 20 meter shuttle run test dan VO2 max sebagai hasil akhir. Hasil berbagai penelitian tersebut di atas didapatkan keseragaman hasil dalam hal perbandingan tingkat aktivitas fisik dan kesegaran jasmani, anak yang aktif memiliki tingkat kesegaran jasmani yang tinggi, sedangkan jenis kelamin dapat juga mempengaruhi tingkat kesegaran jasmani seseorang. Pada penelitian ini didapatkan bahwa anak laki-laki memiliki tingkat kesegaran jasmani yang lebih tinggi, sedangkan berdasarkan aktivitas fisik, anak yang aktif cenderung memiliki VO2 max yang lebih besar dibandingkan yang tidak aktif.

Anak sekolah di daerah pedesaan memiliki skor kualitas hidup yang lebih tinggi dibandingkan dengan anak sekolah di perkotaan. Berdasarkan masing-masing fungsi hanya didapatkan perbedaan skor untuk fungsi 
fisik dan mental, sedangkan fungsi sekolah dan sosial tidak didapatkan perbedaan yang bermakna. Penelitian di Eropa tahun 2006 mengenai kualitas hidup penduduk di desa dan kota, didapatkan hasil tidak ada perbedaan yang bermakna (18). Hal ini terjadi kemungkinan karena di Eropa tidak didapatkan perbedaan kondisi sosial ekonomi antara penduduk yang tinggal di pedesaan dan perkotaan, sedangkan di negara berkembang perbedaan status sosial ekonomi antar kedua daerah tersebut sangat tinggi.

Beberapa penelitian melaporkan perbedaan persepsi antara penduduk daerah pedesaan dan perkotaan mengenai definisi kualitas hidup. Persepsi penduduk di pedesaan tentang kualitas hidup adalah kemampuan untuk bekerja, fungsi harian, dan kondisi tanpa ada gejala penyakit, sedangkan penduduk daerah perkotaan lebih menilai sehat sebagai kondisi tanpa adanya penyakit (19). Di samping itu, akses terhadap pelayanan kesehatan di daerah pedesaan lebih sulit dibandingkan dengan perkotaan.

Hasil penelitian ini menunjukkan kondisi daerah pedesaan yang dianggap memiliki berbagai kekurangan tidak mempengaruhi kualitas hidup anak, bahkan anak di daerah pedesaan memiliki kualitas hidup yang lebih tinggi dibandingkan dengan anak di daerah perkotaan. Hasil tersebut serupa dengan hasil penelitian di Dhaka, Bangladesh yang menemukan bahwa skor mental anak daerah pedesaan lebih baik dibandingkan dengan perkotaan (8). Hal ini terjadi kemungkinan karena pada anak perkotaan ditemukan IMT yang lebih tinggi, tingkat gizi lebih dan obesitas yang tinggi sehingga memiliki skor kualitas hidup yang lebih rendah. Hal ini sesuai dengan hasil penelitian tentang obesitas dan kualitas hidup yang telah dilakukan oleh para ahli sebelumnya. Anak dengan gizi lebih dan obesitas cenderung memiliki kualitas hidup dan mental yang lebih rendah, disamping fungsi fisiknya juga lebih rendah (20-24).

\section{KESIMPULAN DAN SARAN}

Subjek di daerah pedesaan memiliki status gizi yang lebih rendah dibandingkan dengan yang di perkotaan, tetapi lebih aktif dan memiliki tingkat kesegaran jasmani yang lebih tinggi serta memiliki skor untuk kualitas hidup lebih besar terutama terhadap fungsi fisik dan mental. Penelitian lebih lanjut diperlukan untuk melihat seberapa besar faktorfaktor status gizi, aktivitas fisik, kesegaran jasmani, dan kualitas hidup pada anak usia sekolah mempengaruhi perbedaan di daerah perkotaan dan pedesaan dan mencari faktor-faktor yang mempengaruhinya.

\section{RUJUKAN}

1. Li J, Stanley F, McMurray A, Hertzman C, Mattes E. Social determinants of child health and well-being. Health Soc Rev 2009;18(1):3-11.
2. Daryanto A. Disparitas pembangunan perkotaanpedesaan di Indonesia. Agrimedia 2003;8(2):30-9.

3. Ganong L, Beckmeyer J, Benson J, Jamison T, McCaulley G, Sutton E. Poverty in American: rural and urban differences. [serial online] 2007 [cited 2011 March 12]. Avaliable from: http://missourifamilies.org/ cfb/briefs/ruralurban.pdf.

4. Kennedy G, Nantel G, Brouwer ID, Kok FJ. Does living in an urban environment confer advantages for childhood nutritional status? analysis of disparities in nutritional status by wealth and residence in Angola, Central African Republic and Senegal. Public Health Nutr 2006;9(2):187-93.

5. Anwer I, Awan JA. Nutritional status comparison of rural with urban school children in Faisalabad District, Pakistan. Rural Remote Health [serial online] 2003 [cited 2011 March 12];3(1):130. Avaliable from: http:// rrh.deakin.edu.au.

6. de Vries SI, Bakker I, van Mechelen W, Hopman-Rock $M$. Determinants of activity-friendly neighborhoods for children: results from the SPACE study. Am J Health Promot 2007;21(4):312-6.

7. Woo KS, Chook P, Yu CW, Sung RYT, Qiao M, Leung SS, Lam CW, Metreweli C, Celermajer DS. Effects of diet and exercise on obesity-related vascular dysfunction in children. Circulation 2004;109(16):1981-6.

8. Izutsu T, Tsutsumi A, Islam AM, Kato S, Wakai S, Kurita $\mathrm{H}$. Mental health, quality of life, and nutritional status of adolescents in Dhaka, Bangladesh: comparison between an urban slum and a non-slum area. Soc Sci Med 2006;63(6):1477-88.

9. Belizzi MC, Dietz WH. Workshop on childhood obesity: summary of the discussion. Am J Clin Nutr 1999;70(1):173S-5S.

10. WHO. Physical status: the use and interpretation of anthropometry. WHO: Geneva; 1995.

11. Armstrong T, Bull F. Development of a short global physical activity questionnaire (GPAG) for use in developing countries. Geneva: WHO; 2003.

12. Shvartz E, Reibold RC. Aerobic fitness norms for males and females aged 6-75: a review. Aviat Space Environ Med 1990;61(1):3-11.

13. Hodgkin E, Hamlin MJ, Ross JJ, Peters F. Obesity, energy intake and physical activity in rural and urban New Zealand children. Rural Remote Health 2010;10(2):1336.

14. Loucaides CA, Chedzoy SM, Bennett N. Differences in physical activity levels between urban and rural school children in Cyprus. Health Educ Res 2004;19(2):13847.

15. Joens-Matre RR, Welk GJ, Calabro MA, Russell DW, Nicklay E, Hensley LD. Rural-urban differences in physical activity, physical fitness, and overweight prevalence of children. J Rural Health 2008;24(1):49-54. 
16. Gill M, Deol NS, Kaur R. Comparative study of physical fitness components of rural and urban female students of Punjabi University, Patiala. Anthropologist 2010;12(1):17-21.

17. Tsimeas PD, Tsiokanos AL, Koutedakis $\mathrm{Y}$, Tsigilis $\mathrm{N}$, Kellis $S$. Does living in urban or rural settings affect aspects of physical fitness in children? an allometric approach. Br J Sports Med 2005;39(9):671-4.

18. Shucksmith M, Cameron S, Merridew T. First European quality of life survey: urban-rural differences. Denmark: European Foundation for the Improvement of Living and Working Conditions; 2006.

19. Weinert C, Burman ME. Rural health and healthseeking behaviors. Annu Rev Nurs Res 1994;12:6592.
20. Tsai WL, Yang CY, Lin SF, Fang FM. Impact of obesity on medical problems and quality of life in Taiwan. Am J Epidemiol 2004;160(6):557-65.

21. Janicke DM, Marciel KK, Ingerski LM, Novoa W, Lowry $\mathrm{KW}$, Sallinen BJ, Silverstein JH. Impact of psychosocial factors on quality of life in overweight youth. Obesity 2007;15(7):1799-807.

22. Friedlander SL, Larkin EK, Rosen CL, Palermo TM, Redline S. Decreased quality of life associated with obesity in school-ages children. Arch Pediatr Adolesc Med 2003;157(12):1206-11.

23. Cherry DC, Huggins B, Gilmore K. Children's health in the rural environment. Pediatr Clin North Am 2007;54(1):121-33.

24. Yang RK, Fetsch RJ. The self-esteem of rural children. J Res Rural Educ 2007;22(5):1-7. 